\title{
Enhancing the Performance Consistency of Porcelain Insulators by Understanding Failure Modes: Case Study Approach
}

\author{
Mr. Prasanta Ash ${ }^{1}$ and Dr. Kappagomtula C.L ${ }^{2}$ \\ MBA Student, GlobalNxt University, Kuala Lumpur, Malaysia ${ }^{1}$ \\ Professor, GlobalNxt University, Kuala Lumpur, Malaysia ${ }^{2}$
}

\begin{abstract}
World over, 40\% of insulators used in transmission and distribution segment of power are the composite insulators made from polymeric compound. These insulators are very light in weight, almost $1 / 5^{\text {th }}$ of conventional porcelain or glass insulators and cost almost $25 \%$ of the conventional insulators. Thus, they clearly have technical advantage over porcelain insulators because of their hydrophobic property. This feature enables them to withstand very high pollution levels. In tune with the global demand for pollution control, the demand for these composite insulators are increasing simply because, the high pollution causes frequent flashover and disrupt the power supply. The low cost of composite insulators reduces the project cost thus threatening the demand for conventional porcelain insulators. This is affecting their market share in business. A case study has been undertaken to study the Global Insulators Ltd., Dhanbad in India with an intent to, probe into use of composite insulators, which have not been time tested for their sustenance in the face of their frequent failures, despite their enhanced hydrophobic property. The study is intended to find a reprieve for demand of the conventional porcelain insulators through root cause analysis of failure and suggest ways to enhance their di-electric properties to increase their life. In order to safe guard the business interest of the manufacturer; the name has been changed along with altered data values without affecting the outcome for the results.
\end{abstract}

Keywords: Composite, Insulators, di-electric, root cause, hydrophobic.

\section{INTRODUCTION}

Porcelain insulators were manufactured first in 1890's and since then, ceramics (porcelain, glass) insulators have been the only choices at high voltages insulator application. By 1930 high tension electric transmission was well established by using quartz-enriched porcelain insulators due to its excellent dielectric and mechanical strength. High voltage porcelain insulators were the first choice for any transmission line due to its long operating life and due to its historical performance.

The first polymeric insulators were developed by General Electric (GE) in 1959 but it was never used in any big commercial way. Many countries were using it sporadically for its better properties in polluted areas due to its higher hydrophobic property. Till the year 1990, it was porcelain as the first choice for transmission or distribution insulators.

However, due to the changes in environmental condition (the pollution levels), the cost of laying lines, supply-chain issues and few critical failures of porcelain in transmission lines necessitated the need to think for an alternative. Now a days, polymeric insulators have gained a market of nearly $40 \%$ of total transmission and distribution network and it is constantly growing faster, giving a big challenge to porcelain insulators.
It has now become a question of survival for the porcelain insulators industry. A typical porcelain insulator is shown in Figure 1. This is used in power transmission line carrying $11 \mathrm{KV}$ to $1200 \mathrm{KV}$ of electricity. The construction of the insulatorremains same except the rating of insulators changes depending on the line carrying capacity. If we look into the design, we have one porcelain part, two metal parts and two cement portions. Load is applied in two directions along with electrical influence.

Insulators are subjected to $45 \mathrm{KN}$ to $500 \mathrm{KN}$ tensile load apart from their insulating properties when they are in the application. This makes the thing more complicated and delicate, for we need to have the properties maintained for porcelain, cement mortars and metals to complement with each other. Hence it is very important to quantify each and every variable and ensure their measurements.

The internal records of testing, at Global Insulators Ltd., located at Dhanbad in India indicate around $2 \%$ internal failures of insulators. This primarily indicates some influence of specific variable(s) causing this failures, it is not problems connected with the fundamental design or material used in manufacturing. Exploring for this unknown variable(s), set the impetus for the current case study by the authors. 


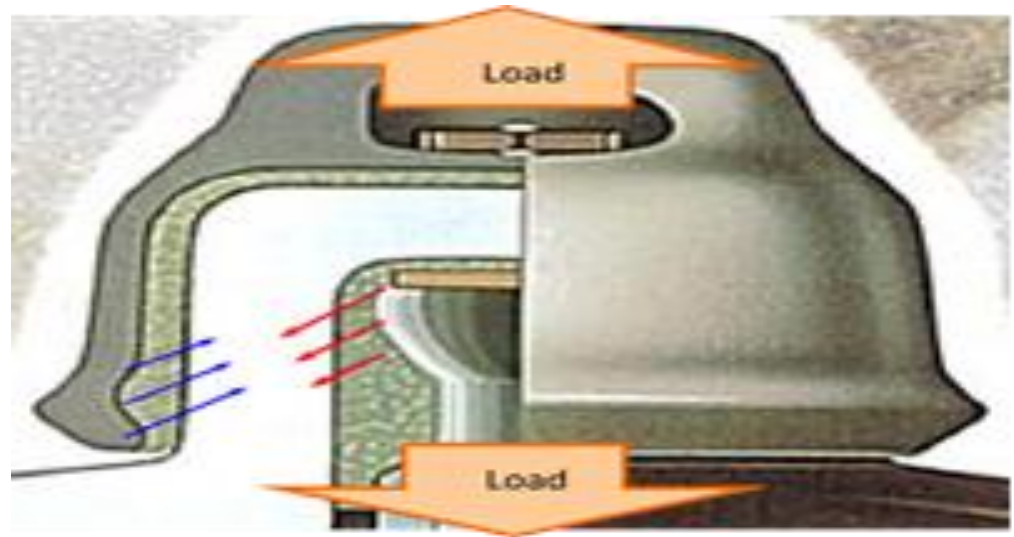

Figure 1: Construction of a typical Porcelain Insulator

The insulators are all pervasive, right from power generation source to the feeder system and then for extended range of power transmission to every nook and corner in the World where electricity is used. This is depicted in Figure 2.

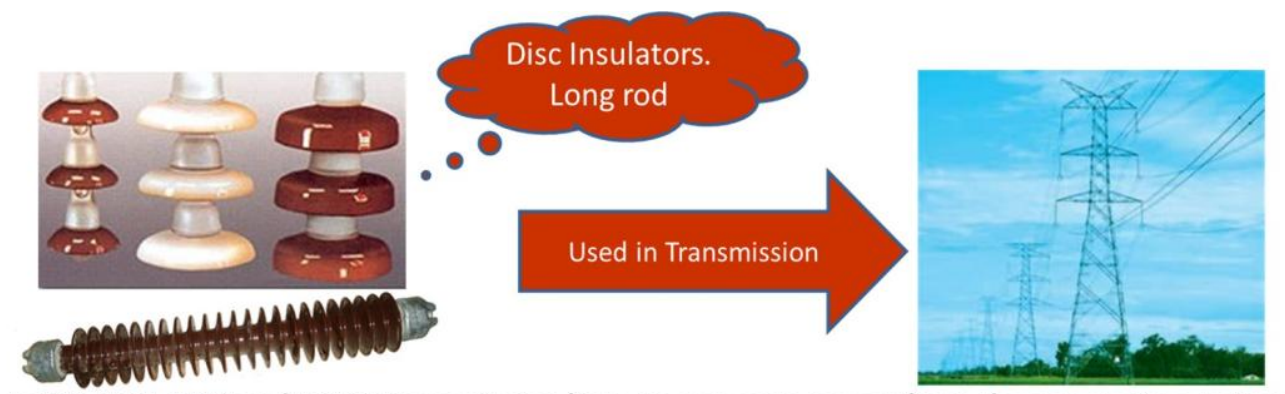

In HV, EHV, UHV and HVDC transmission lines to evacuate power from the generating stations.

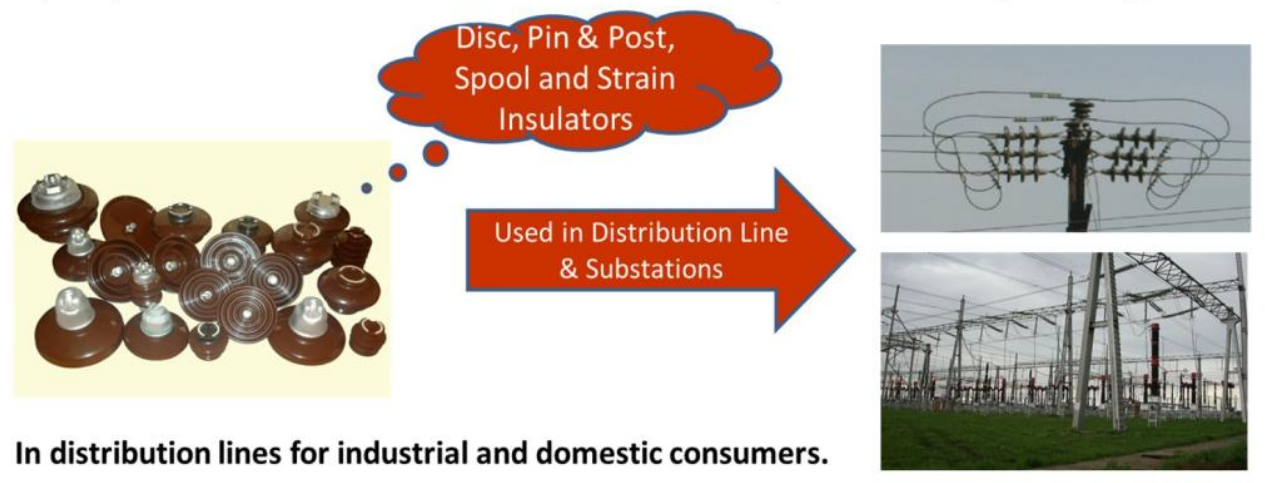

Figure 2: Applications for insulators

The manufacturing process of porcelain insulators has manufacturing a skillful technology. Unlike other ceramic many steps (Refer to Figure 3). It has a fairly long process porcelain products like sanitary ware, chinaware, tiles, cycle ranging from 15 days to 21 days. Adding to this long porcelain insulators' manufacturing units are very few process cycle, porcelain insulators have to pass through across the world due to this long product manufacturing almost 35 process steps. Each process steps has its own cycle.Not going into further details, it is worthwhile to importance and contribute to the quality and performance emphasize the fact that manufacturing porcelain insulator of the insulators. It is a transformation of raw earthy is not a simple process and needs a high degree of control materials like clay, quartz, and feldspar into an electrical in the processes. This study becomes more relevant with equipment used in electrical power system. It is then respect to this aspect in mitigating defects right from the becomes the backbone of electrical power transmission manufacturing process stage.

and distribution system as insulators.

The efficiency of the system depends on the supply The variation of naturally occurring raw materials, long continuity and losses. To maintain supply continuity, processing time, multiple process steps and a significant major challenges nowadays to the electricity companies is number of product tests make the process of insulator pollution levels across the world. The pollutant deposits on 
the surface of Insulators and reduction of the insulation power grid system. The severity of these failures can be properties causes flashover. Continuous flashover leads to very high.

the disruption of supplies and can cause havoc in the entire

\section{PROCESS FLOW DIAGRAM}

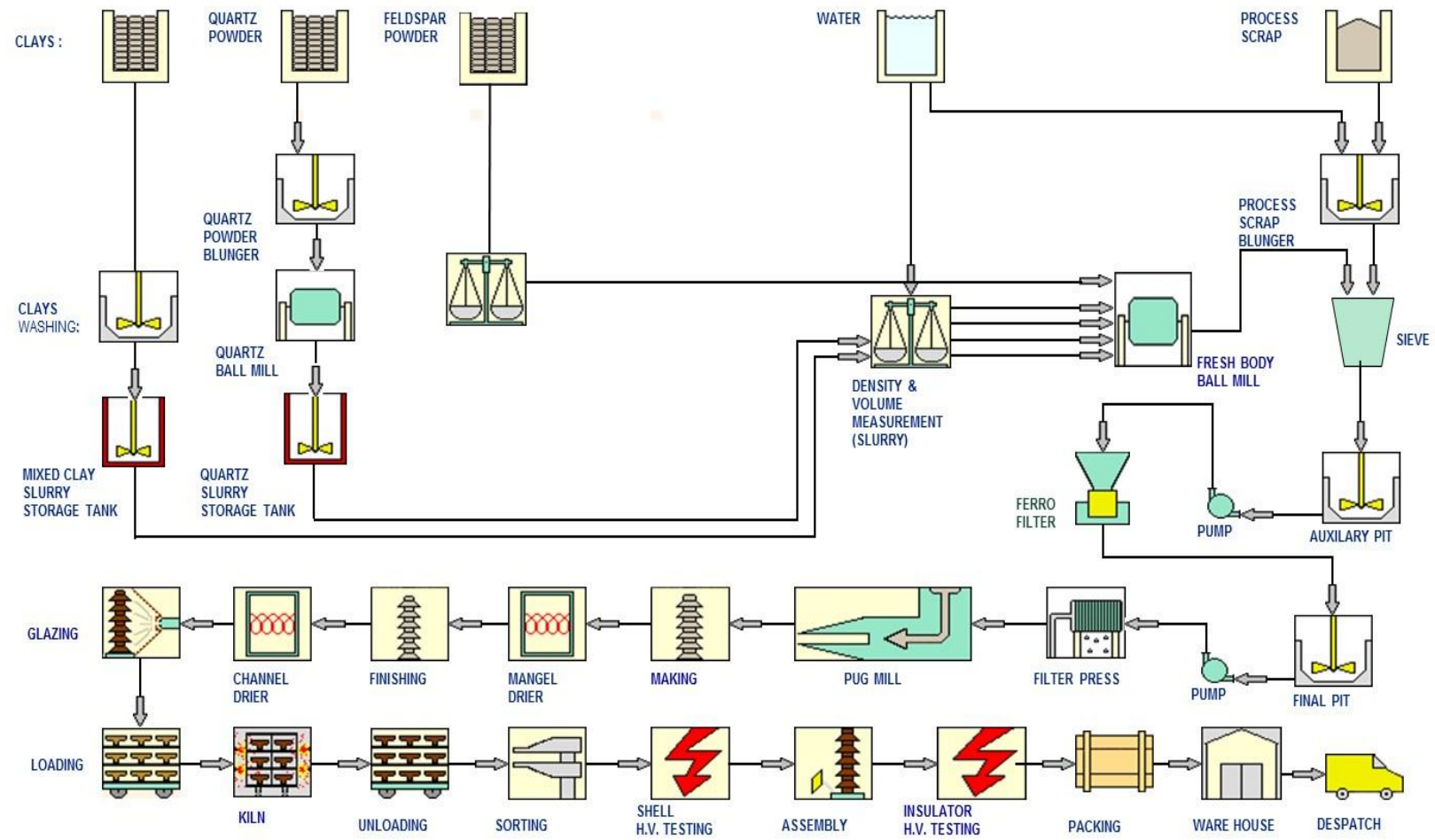

Figure 3: Manufacturing process of porcelain insulators

Some details of few mega failures of lines will throw light can withstand very high pollution level. Since globally, the on the devastation it can cause in human life and is shown pollution levels are increasing, choice of composite in Table 1. This gives details of the major and catastrophic insulators are also increasing. Due to this high pollution, grid failure at various parts of the world during the last there is frequent flashover causing the porcelain to fail and five decades. Since 1965 to 2009, worldwide 128 major disrupt the power supply.Further, the price for composite power outages happened and in many cases it was is low and manufacturing is easy. Thus the low-price attributed to the weather or storm or heavy winds. All reduces the project cost. This affects the business for these are natural causes of failure. In US, Canada, and in retailers for these products. The increase in composite Europe the failures are mainly attributed to weather. While insulators means a reduction in demand forporcelain in rest of the world, the trend is slightly different. The insulators affecting the trade.

failures are attributed to substation failures or transmission line failures, not much related to weather. This needs a systematic analysis before drawing any conclusion.

A silver line in this adverse situation is - though the composites have a better hydrophobic property, its working life is yet to be established. There are many preIn the present scenario of transmission and distribution mature failures in the composites which raise doubt on this segment of power transmission, $40 \%$ insulators are used product. But till there is an alternate to combat pollution, which are made from polymeric compound, the composite will dominate. So for the survival, the called"Composite insulators". These insulators are very business is looking into identifying the root cause of light in weight, almost $1 / 5$ th of porcelain or glass failure due to higher pollution and how to enhance the insulators and 1/4th in price to that of porcelain insulators. dielectric properties of porcelain insulators to provide a They have one clear technical advantage over porcelain, solution to the power industry. "A better insulators and which is, they have high hydrophobic property and hence higher life means a blooming business for the dealers". 
IJIREEICE

International Journal of Innovative Research in Electrical, Electronics, Instrumentation and Control Engineering

ISO 3297:2007 Certified

Vol. 5, Issue 2, February 2017

Table 1: Major global grid failures during the last 5 decades

\begin{tabular}{|l|c|l|l|}
\hline \multicolumn{4}{|c|}{ MAJOR GRID FAILURES ACROSS THE WORLD } \\
\hline Details & $\begin{array}{c}\text { Millions of } \\
\text { People affected }\end{array}$ & \multicolumn{1}{c|}{ Location } & \multicolumn{1}{c|}{ Date } \\
\hline 2012 July North India Blackout & $\mathbf{6 7 0}$ & India & $30-31$ July 2012 \\
\hline 2005 Java- Bali Blackout & $\mathbf{1 0 0}$ & Indonesia & $18^{\text {th }}$ August 2005 \\
\hline 1999 Southern Brazil Blackout & $\mathbf{9 7}$ & Brazil & $11^{\text {th }}$ March 1999 \\
\hline 2009 Brazil and Paraguay Blackout & $\mathbf{8 7}$ & Brazil, Paraguay & $10-11$ November 2009 \\
\hline 2003 Northeast Blackout & $\mathbf{5 5}$ & USA and Canada & $14-15$ August 2003 \\
\hline 2003 Italy Blackout & $\mathbf{5 5}$ & $\begin{array}{l}\text { Italy, Switzerland, Austria, } \\
\text { Slovenia, Croatia }\end{array}$ & $28^{\text {th }}$ September 2003 \\
\hline 1965 Northeast Blackout & $\mathbf{3 0}$ & USA and Canada & $9^{\text {th }}$ November 1965 \\
\hline
\end{tabular}

(Source: Presentation by Sourabh Lodha - Department of Electrical Engineering, CDSE)

\section{SIGNIFICANCE OF THE STUDY}

There has been many failure analysis and studies being made in the past as are enumerated above. Various literature and internal documents provide those details. However, these studies do not answer the following questions, which forms the 'gap' providing the impetus for this study:

(i) How the composite insulator leakage current varies with respect to relative humidity under polluted conditions?

(ii) Where exactly the maximum electrical filed stress occurs in the polluted composite insulator under different wet conditions?

(iii) How different types of features can be extracted from the measured LC? and

(iv) Which type of feature among that will be used to predict the surface condition exactly?

Methods were developed to predict the surface condition of insulator but these are mostly based on the ceramic insulator models. Hence, there is a need for developing accurate automated surface condition monitoring system for composite insulators. The testing of insulator in laboratory is very expensive. Many models have been proposed to predict the insulator leakage current but only a few models are related to composite insulator with many assumptions. This study document is mainly addressing the above mentioned issues which hitherto were not discussed or found in literature study with vivid details. These are the foundation forthis Study.

As for the business is concerned, Global Insulators Ltd., are the-

- World's fourth largest and one of India's largest producers in insulators

- Manufacturer of High-performance Porcelain and Composite insulators for Transmission \& Distribution sector.

- Insulators of the concern are used to run electricity in 58 countries
- Around 5000 personnel in the workforces

- Many ancillaries and vendors to support the business.

In recent past, due to insurgent of composite insulators and heavy import from China, two major insulator manufacturers (for transmission line) have closed down their manufacturing operations. This is a big challenge for the industry to survive and protect its business. The growth of Indian insulators' demand forces the manufacturer to look beyond the territorial boundaries. To make a success story and continued business both indomestic and ininternational markets, it is essential to have a robust product to meet international quality norms that are very stringent and comprehensive. Thisstudy, thereforeassumes more significance in the light of the present situation and for the sustainable growth of the business over the years.

The insulators used for transmission lines are governed by national and international standards. The failure of insulators can cause a catastrophic effect on the power grids resulting in huge losses and even fatal accidents.

Hence these standards are very stringent and exhaustive. Every insulator has to mandatorily pass through these quality checks. The economic impact of insulator flashovers can be severe. According to CEA Enquiry Committee report (2008) and Muniraj et.al (2013) research paper on, grid disturbance in India have resulted in huge losses to the order of five thousand million Indian rupees.IS, IEC, ANSI are the few national and international standards being followed.

\section{OBJECTIVES FOR THE STUDY}

As per the survey report of 'Insulators News and Market Report' (INMR) of September 2016 the global demand for insulators in transmission and distribution of power will reach to 6.5 Billion USD in the world markets, by 2025 corroborated byGaulden estimates- a British consulting organization that provides market intelligence to the electrical industry. In 2010, the porcelain market share was above $50 \%$ and polymeric (composite) insulators were $39 \%$, while in 2015, the Market share forporcelain has 
dropped to $48 \%$ and for the composite, it has increased to $40 \%$.

Globally the liking for composite insulators are on therise due to its advantages. Hence it is essential for the porcelain manufacturers to provide a better solution and to combat the onslaught of composite insulators, if that manufacturer has to be 'market competitive'. The objective of this study is to find out the probable causes of failure (Puncture) and enhance the performance / durability of porcelain insulators in any given condition.In manufacturing of porcelain insulators, there are many variables. Our objective in this case study is to find out, the most critical variables and their optimum values which can provide best results.

\section{THE CASE QUESTION}

The authors have set in to find through this study: Will it be possible to enhance the long-term performance of porcelain insulators to create a Unique Selling Point (USP) over Composite Insulators?

\section{LITERATURE SURVEY}

Hydrophobicity transfer (HT) is a measure of the ability to recover the hydrophobicity of the material (e.g. silicone rubber). This is done by the diffusion of Low Molecular Weight (LMW) silicones through the pollution layer to the surface and encapsulation of pollution particles including salt. Even if the polluted surface appears to be hydrophilic at the top, part of the pollution layer is penetrated by LMW silicones and the effective resistance has been increased. The HT is defined as:

$$
H T=\frac{E S D D-A S D D}{E S D D}
$$

Where, ASDD is the so-called Apparent Salt Deposit Density (or Localized ESDD). Both ESDD and ASDD are measured with a small cell filled with de-ionized water where the bottom is the surface of the polluted insulator. ASDD is measured initially as current through the cell when the encapsulated pollution has not yet dissolved. After 5 minutes or when the current level has stabilized the bottom surface of the cell is scraped with a glass rod whereby the encapsulated pollution is set free. This measure is taken as ESDD. (INMR, 2016)

Insulator failure is clearly something that every power supply company wishes would never occur. However, it is unrealistic to expect that every insulator will last forever and never fail. Therefore, one can reasonably expect that some will fail after a certain time in service. Fortunately, most HV insulators today have reached a high level of reliability. Still, failures can and do occur due to inferior design and materials, improper manufacturing, misapplication of the insulator for its intended service environment or extreme stresses linked to weather, vandalism, wildlife or mishandling. The result will be some faults that results in failure of insulators, such as Radial cracking, Pin corrosion, Brittle fracture etc. (INMR, 2015)

According to the British Standard, the electrical insulator must undergo the following tests:

1. Flashover tests of insulator,

2. Performance tests and

3. Routine tests Lets have a discussion one by one-

Flashover Test: There are mainly three types of flashover test performed on an insulator and these are -

Power Frequency Dry Flashover Test of Insulator

1. First the insulator to be tested is mounted in the manner in which it would be used practically.

2. Then terminals of variable power frequency voltage source are connected to the both electrodes of the insulator.

3. Now the power frequency voltage is applied and gradually increased up to the specified value. This specified value is below the minimum flashover voltage.

4. This voltage is maintained for one minute and observe that there should not be any flash-over or puncher occurred. The insulator must be capable of sustaining the specified minimum voltage for one minute without flash over.

Power Frequency Wet Flashover Test or Rain Test of Insulator

1. In this test also the insulator to be tested is mounted in the manner in which it would be used practically.

2. Then terminals of variable power frequency voltage source are connected to the both electrodes of the insulator.

3. After that the insulator is sprayed with water at an angle of 450 in such a manner that its precipitation should not be more $5.08 \mathrm{~mm}$ per minute. The resistance of the water used for spraying must be between $9 \mathrm{k} \Omega 1011 \mathrm{k} \Omega$ per $\mathrm{cm} 3$ at normal atmospheric pressure and temperature. In this way we create artificial raining condition.

4. Now the power frequency voltage is applied and gradually increased up to the specified value.

5. This voltage is maintained for either one minute or 30 second as specified and observe that there should not be any flash-over or puncher occurred. The insulator must be capable of sustaining the specified minimum power frequency voltage for specified period without flash over in the said wet condition.

Power Frequency Flashover Voltage test of Insulator

1. The insulator is kept in similar manner of previous test.

2 . In this test the applied voltage is gradually increased in similar to that of previous tests.

3. But in that case the voltage when the surroundings air breaks down, is noted. 


\section{International Journal of Innovative Research in Electrical, Electronics, Instrumentation and Control Engineering ISO 3297:2007 Certified}

Vol. 5, Issue 2, February 2017

Impulse Frequency Flashover Voltage Test of Insulator The overhead outdoor insulator must be capable of sustaining high voltage surges caused by lightning etc. So this must be tested against the high voltage surges.

1. The insulator is kept in similar manner of previous test. 2. Then several hundred thousand $\mathrm{Hz}$ very high impulse voltage generator is connected to the insulator. 3. Such a voltage is applied to the insulator and the spark over voltage is noted.

The ratio of this noted voltage to the voltage reading collected from power frequency flashover voltage test is known as impulse ratio of insulator.

This ratio should be approximately 1.4 for pin type insulator and 1.3 for suspension type insulators.

Performance Test of Insulator

Now we will discuss performance test of insulator one by one-

Temperature Cycle Test of Insulator

1. The insulator is first heated in water at $70 \mathrm{oC}$ for one hour.

2. Then this insulator immediately cooled in water at $7 \mathrm{oC}$ for another one hour.

3. This cycle is repeated for three times.

4. After completion of these three temperature cycles, the insulator is dried and the glazing of insulator is thoroughly observed.After this test there should not be any damaged or deterioration in the glaze of the insulator surface.

Puncture Voltage Test of Insulator

1. The insulator is first suspended in an insulating oil.

2. Then voltage of 1.3 times of flash over voltage, is applied to the insulator.

A good insulator should not puncture under this condition. Porosity Test of Insulator

1. The insulator is first broken into pieces.

2. Then these broken pieces of insulator are immersed in a $0.5 \%$ alcohol solution of fuchsine dye under pressure of about $140.7 \mathrm{~kg} / \mathrm{cm} 2$ for 24 hours. 3 . After that the sample are removed and examine. The presence of a slight porosity in the material is indicated by a deep penetration of the dye into it.

Mechanical Strength Test of Insulator

1. The insulator is applied by $2 \frac{1}{2}$ times the maximum working strength for about one minute. The insulator must be capable of sustaining this much mechanical stress for one minute without any damage in it.

Routine Test of Insulator

Each of the insulator must undergo the following routine test before they are recommended for using at site.

Proof Load Test of Insulator

In proof load test of insulator, a load of $20 \%$ in excess of specified maximum working load is applied for about one minute to each of the insulator.
Corrosion Test of Insulator

In corrosion test of insulator,

1. The insulator with its galvanized or steel fittings is suspended into a copper sulphate solution for one minute.

2. Then the insulator is removed from the solution and wiped, cleaned.

3. Again it is suspended into the copper sulphate solution for one minute.

4. The process is repeated for four times

As such there is no direct article available in this field. There are many discrete articles on this matter, but no comprehensive one.

The Major manufacturer Like NGK- Japan, LAPP - US, Siemens - Germany have their website stating few details but these are restricted information.INMR (Independent T \& D Resource) and IEEEMA (Indian Electrical and Electronics Manufacturers' Association) are two authorized sources providing information on various technical developments and performances of insulators across the world.

\section{GAP ANALYSIS}

- Failures of insulators due to pollution flashover can prove very costly, causing potentially long outages and requiring expensive and time-consuming maintenance. By most accounts, one of the leading causes of such failures is improper specification of insulators in the first place - to the extent that the designs selected are unable to cope with all the stresses imposed by pollution in the environment. Therefore, it is vital for engineers at power supply companies to correctly understand the real pollution characteristics of the service environment into which insulators will be different pollution monitoring techniques as well as presented principles to convert from one parameter to another placed into service. This second of a two-part INMR article from 2012, was contributed by Igor Gutman of STRI and Wallace Vosloo of Eskom. It introduced practical field and laboratory experience with. It also discussed how to use these parameters for insulator dimensioning according to the requirements of the IEC 60815 .

- Failure modes and electrical and mechanical strengths of porcelain and toughened glass insulators that have been in service for many years. The findings are based on a vast body of published literature, as well as a study performed on insulators that were in service for up to 70 years. The insulators were tested for insulation resistance, dielectric strength, porosity and residual mechanical strength. The microstructure of the porcelain was analyzed using a scanning electron microscope. Significant differences in the compositional and microstructure details of porcelain insulators were observed. The electrical and mechanical strengths of porcelain insulators was found to vary significantly from one manufacturer to another, with some aged insulators showing marginal changes and others 
showing significant reduction in these parameters. Glass insulators evaluated showed small reduction in their residual mechanical strength when compared to new ones. These differences should have significant impact on system reliability and maintenance procedures adopted by utilities. (Gorur, 2011).

- The main cause of failure of overhead line insulator, is flash over, which occurs in between line and earth during abnormal over voltage in the system. During this flash over, the huge heat produced by arcing, causes puncher in insulator body. Viewing this phenomenon the materials used for electrical insulator, has to possess some specific properties. Properties of Insulating Material needed are: (Christine Chang, 2016)

i) It must be mechanically strong enough to carry tension and weight of conductors.

ii) It must have very high dielectric strength to withstand the voltage stresses in High Voltage system.

iii) It must possesses high Insulation Resistance to prevent leakage current to the earth.

iv) The insulating material must be free from unwanted impurities.

v) It should not be porous.

vi) There must not be any entrance on the surface of electrical insulator so that the moisture or gases can enter in it.

vii) There physical as well as electrical properties must be less effected by changing temperature.

The impact of Pollution is well illustrated in the article "Insulator pollution in transmission lines". (Parihar \& Kori, 2015)It is one of the single largestreason for the failure of Insulators across the world. The pollutants are deposited on the insulator surface carried by winds. The pollution can be from Sea salt, Industrial waste, Agricultural gasses etc. thus formed a layer on the surface. These layers, when get dampened by rain or fog, enlarges conductivity. When this contaminant layer dries it increases the leakage current. Partial arches appear through the dry bands and partial discharges are produced. Finally, total discharge is produced.

A detailed classification of types of pollutants and their sources were discussed in this article. The impact of these on Insulators and how the maintenance of insulators can lead to failures was another discussion point. Another possible solution to combat pollution had been discussed in this Article. It is a coating of silicon grease over the surface of insulators called RTV (Room temperature Volcanized) silicon to increase the hydrophobicity of Insulator surface. The hydrophobic property helps in selfcleaning of insulator surface and prevent deposition of Pollutants.

Other articles describe the importance of selection of Insulators considering pollution levels and pollution performances. The testing process of insulators and associated failures were also highlighted. One significant study is given in the article "Mechanical_- Electrical Stress Studies of Porcelain Insulator Bodies "worth mentioning (Parmelee \& Kraehenbuehl, 1935). The aging effect on insulators is predominant on porcelain than Toughened Glass.

Even Polymeric insulators are also subjected to aging and performance deterioration. From the literature survey and the gap analysis leads to the essence, as an alternate improvement, the possibility of RTV coating over Porcelain is considered as one solution to counteract the influence of composite insulators. It has advantages of both Porcelain and hydrophobic properties of Polymers. This is one solution which is being tried more in substations. The process of application, handling and the additional cost is the challenges being faced by this technology.

\section{STUDY METHOD}

- Making new dies and tooling to increase Creepage and Cavity Dia.

- Make Samples with New Dies

- Take the similar quantity of Existing Standard Products.

- Firing, Shell Testing and Assembly in Similar condition for two sets of Products.

- Conduct Routine Mechanical and Electrical Test.

- Conduct Temperature cycle test followed by PF.

- Compare results of EMS, Under Oil Puncture for both Sets of Samples

- Conduct Thermal Run Away test subjecting insulators to an accelerated aging condition.

(Followed by EMS, Under Oil Puncture for both Sets of Samples)

Evaluation and analysis two sets of data and derive at the conclusion:

Table 9: Comparative Test result of 120 KN Standard Vs Modified

\begin{tabular}{|c|c|c|c|c|c|c|}
\hline \multirow{2}{*}{$\begin{array}{l}\text { Sl } \\
\text { No }\end{array}$} & \multirow{2}{*}{ Type of Test } & \multirow{2}{*}{ Unit } & \multirow{2}{*}{ Specification } & \multicolumn{2}{|c|}{ Values } & \multirow{2}{*}{ Remarks } \\
\hline & & & & Standard & Modified & \\
\hline \multirow{2}{*}{1} & Dimension : & & & & & \multirow{2}{*}{$\begin{array}{l}\text { Creepage increased } \\
\text { marginally and Cavity ID }\end{array}$} \\
\hline & a) Diameter: & $\mathrm{Mm}$ & $255+/-11$ & 257 & 257 & \\
\hline
\end{tabular}


IJIREEICE

International Journal of Innovative Research in Electrical, Electronics, Instrumentation and Control Engineering

ISO 3297:2007 Certified

Vol. 5, Issue 2, February 2017

\begin{tabular}{|c|c|c|c|c|c|c|}
\hline & b) Cavity ID : & $\mathrm{mm}$ & NA & 39 & 41.5 & \multirow[t]{2}{*}{ increased by $2.5 \mathrm{~mm}$} \\
\hline & c) Creepage Distance : & $\mathrm{mm}$ & $320 \mathrm{~mm}$ (Min) & 335 & 339 & \\
\hline \multirow{5}{*}{2} & Temp. Cycle : & & & & & \multirow{5}{*}{$\begin{array}{l}\text { All pieces withstood and } \\
\text { there is no failure in } \\
\text { Mallet test. }\end{array}$} \\
\hline & Hot : & ${ }^{\circ} \mathrm{C}$ & & 85 & 85 & \\
\hline & Cold : & ${ }^{\circ}{ }^{\circ} \mathrm{C}$ & & 8 & 6 & \\
\hline & Diff : & ${ }^{\circ} \mathrm{C}$ & Diff $>70^{\circ} \mathrm{C}$ & 77 & 79 & \\
\hline & No of Cycle: & Nos. & 3 & 3 & 3 & \\
\hline 3 & PF Withstand (Dry) : & $\mathrm{KV}$ & $\begin{array}{l}70 \mathrm{KV} \text { for } 1 \\
\text { Min }\end{array}$ & 72 & 75 & $\begin{array}{l}\text { In both the cases values } \\
\text { meet specification. } \\
\text { Modified samples are } \\
\text { better by } 5 \% \text {. }\end{array}$ \\
\hline \multirow{6}{*}{4} & EMS : (Sample Size 20) & & & & & \multirow{6}{*}{$\begin{array}{l}\text { In both the cases values } \\
\text { meet specification. } \\
\text { Modified samples are } \\
\text { better by } 10 \% \text {. }\end{array}$} \\
\hline & Avg : & $\mathrm{KN}$ & & 157.85 & 175.25 & \\
\hline & Min : & KN & 120 & 142 & 150 & \\
\hline & Max : & $\mathrm{KN}$ & & 175 & 207 & \\
\hline & Std. Dev (s) : & & & 9.21 & 14.43 & \\
\hline & $\mathrm{R}+3 \mathrm{~s}$ & & Avg $>=R+3 s$ & 147.64 & 163.28 & \\
\hline \multirow{4}{*}{5} & $\begin{array}{l}\text { Oil Puncture : (Sample } \\
\text { Size 10) }\end{array}$ & & & & & \multirow{4}{*}{$\begin{array}{l}\text { In Both the cases values } \\
\text { are above specification. } \\
\text { Though the Average value } \\
\text { of Standard Item is higher } \\
\text { than Modified Sample, but } \\
\text { the overall variation is } \\
\text { low. }\end{array}$} \\
\hline & Avg: & KV & & 174 & 168.5 & \\
\hline & Min : & $\mathrm{KV}$ & 120 & 130 & 140 & \\
\hline & Max : & KV & & 200 & 190 & \\
\hline 6 & $\begin{array}{l}\text { PF Flashover (Dry) : } \\
\text { (Sample Size 10) }\end{array}$ & KV & 75 & 83.5 & 86.5 & $\begin{array}{l}\text { In both the cases values } \\
\text { meet specification. } \\
\text { Modified samples are } \\
\text { better by } 4-5 \% \text {. }\end{array}$ \\
\hline 7 & \multicolumn{6}{|c|}{ Conducted Thermal Runaway Test of 10 Nos of each type, followed by EMS \& O/P } \\
\hline \multirow{6}{*}{8} & EMS : (Sample Size 5) & & & & & \multirow{6}{*}{$\begin{array}{l}\text { After Accelerated Aging, } \\
\text { the values are almost } \\
\text { similar. }\end{array}$} \\
\hline & Avg: & $\mathrm{KN}$ & & 161 & 166.2 & \\
\hline & Min : & KN & 120 & 150 & 147 & \\
\hline & Max : & $\mathrm{KN}$ & & 170 & 182 & \\
\hline & Std. Dev (s) : & & & 8.22 & 12.79 & \\
\hline & $\mathrm{R}+3 \mathrm{~s}$ & & $\operatorname{Avg}>=R+3 s$ & 144.65 & 158.38 & \\
\hline \multirow{4}{*}{9} & $\begin{array}{l}\text { Oil Puncture : (Sample } \\
\text { Size 5) }\end{array}$ & & & & & \multirow{4}{*}{$\begin{array}{l}\text { In both the cases values } \\
\text { meet specification. } \\
\text { Modified samples are } \\
\text { better by } 10 \% \text {. }\end{array}$} \\
\hline & Avg: & $\mathrm{KV}$ & & 167 & 185 & \\
\hline & Min : & $\mathrm{KV}$ & 120 & 160 & 175 & \\
\hline & Max : & $\mathrm{KV}$ & & 175 & 195 & \\
\hline
\end{tabular}

\section{THE CASE DESIGN}

Fundamental study of Failure modes of Insulators and deriving the root causes of these failures would help to understand the Improvements to be made in specific areas of Manufacturing to establish "Long Term Reliability".The case study focuses two aspects:

1. Root Cause Analysis of Internal Failures

2. Design modification to increase performance.
Aspect 1: Root cause analysis for Insulators' defect (Puncture):

Puncture in insulators could be due to any of the contributing parameters, shown in Figure 4.

The components / parameters for causing puncture could be due to Ceramic body, Dimensional error, Sintering, Defective assembly, Metal parts, or defects caused due to 'force de-majeure' 
IJIREEICE

International Journal of Innovative Research in Electrical, Electronics, Instrumentation and Control Engineering

ISO 3297:2007 Certified

Vol. 5, Issue 2, February 2017

Fish Bone Diagram - Puncture
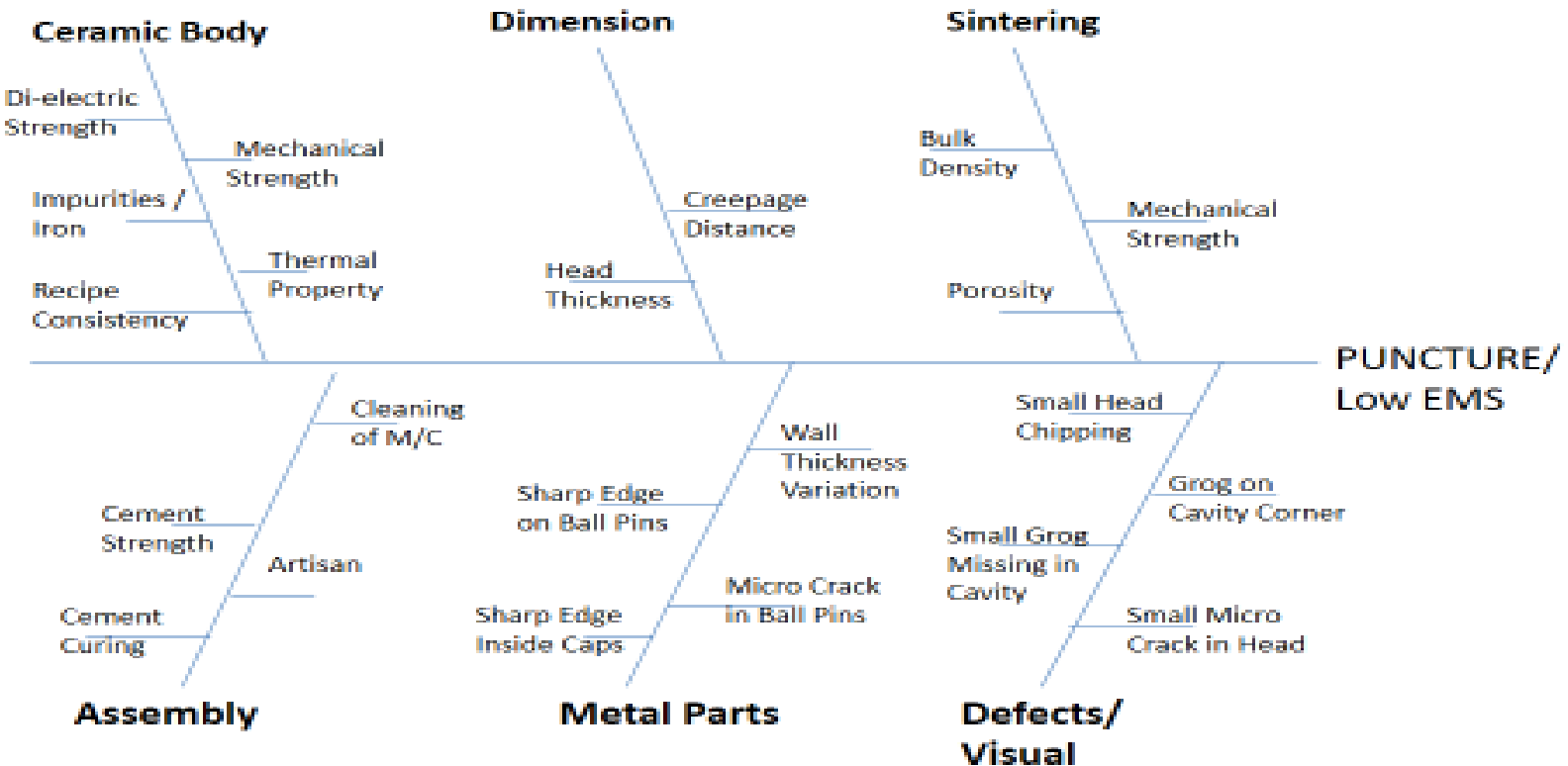

Figure 4: Insulator puncture (root cause analysis)

Source: Global Insulators Ltd., India

The detailed analysis of all these contributing factors, is shown in Tables 2 to 7 below:

Table 2: Analysis of Individual Heads of Fish Bone Diagram - Ceramic Body

\begin{tabular}{|c|c|c|}
\hline Sub Heads & Observations & Action Plan \\
\hline $\begin{array}{l}\text { Recipe } \\
\text { Consistency }\end{array}$ & $\begin{array}{l}\text { - No Change in Recipe as verified last } 5 \text { years } \\
\text { data. } \\
\text { - No New Raw material vendors added. } \\
\text { - Slip Density, Viscosity, and other properties } \\
\text { remain Stable and within specified limit. }\end{array}$ & - Maintain the process. \\
\hline $\begin{array}{l}\text { Thermal } \\
\text { Properties }\end{array}$ & $\begin{array}{l}\text { - Thermal expansion at } 650 \text { Deg. verified for last } \\
5 \text { years and consistency in data seen. } \\
\text { - Thermal property related to Body Recipe and } \\
\text { Firing Condition. Stability of this property } \\
\text { indicates stability of Recipe and compatibility } \\
\text { with Kiln Firing Cycle. }\end{array}$ & - Maintain the Process. \\
\hline $\begin{array}{l}\text { Impurities/ } \\
\text { Iron }\end{array}$ & $\begin{array}{l}\text { Well within specified Limit both free Iron and } \\
\text { Chemical Iron. } \\
\text { - The test pieces showing no Impurities. }\end{array}$ & $\begin{array}{l}\text { - } \quad \text { Maintain the Process. } \\
\text { Further improvement planned to } \\
\text { increase permanent Magnet in Slip } \\
\text { Tank, Additional Ferro-Filters in } \\
\text { Slip Line and Increased periodicity } \\
\text { for Gauss Value measurement. }\end{array}$ \\
\hline $\begin{array}{l}\text { Mechanical } \\
\text { Strength }\end{array}$ & $\begin{array}{l}\text { - Fire Bending Strength of Body - Flexural Test. } \\
\text { - Last } 5 \text { years data showing very good } \\
\text { consistency. }\end{array}$ & - Maintain the Process. \\
\hline $\begin{array}{l}\text { Di-electric } \\
\text { Strength }\end{array}$ & $\begin{array}{l}\text { The di-electric value of Ceramic Body (Silica } \\
\text { Body)- Required Min. } 20 \mathrm{KV} / \mathrm{mm} \text {. } \\
\text { - All Data points are more than } 20 \mathrm{KV} / \mathrm{mm}\end{array}$ & - Maintain the process. \\
\hline
\end{tabular}


IJIREEICE

International Journal of Innovative Research in Electrical, Electronics, Instrumentation and Control Engineering

ISO 3297:2007 Certified

Vol. 5, Issue 2, February 2017

Table 3: Analysis of Individual Heads of Fish Bone Diagram - Dimension

\begin{tabular}{|l|l|l|}
\hline Sub Heads & Observations & Action Plan \\
\hline Head Thickness & $\begin{array}{l}\text { The head thickness of Shell and Tested } \\
\text { pieces checked and tabulated. } \\
\text { - Thickness Varies from } 17 \mathrm{~mm} \text { to } 19 \mathrm{~mm} \\
\text { - Required Thickness } 18 \mathrm{~mm} .\end{array}$ & $\begin{array}{l}\text { Study the impact of Lower and } \\
\text { Higher Head Thickness on Puncture } \\
\text { and }\end{array}$ \\
\hline Creepage Distance & $\begin{array}{l}\text { - Creepage distance maintained in positive } \\
\text { side with 5-7 mm more. }\end{array}$ & $\begin{array}{l}\text { Trial to increase Creep age distance } \\
\text { for better electrical properties. }\end{array}$ \\
\hline
\end{tabular}

Table 4: Analysis of Individual Heads of Fish Bone Diagram - Sintering

\begin{tabular}{|c|c|c|}
\hline Sub Heads & Observations & Action Plan \\
\hline Porosity & - No Incidence of porosity in Test samples. & - Maintain the Process \\
\hline Mechanical Strength & $\begin{array}{l}\text { - Hydraulic Proof testing of Shell for } \\
\text { Mechanical Strength. } \\
\text { - } 10 \text { " } 120 \mathrm{KN} \mathrm{SMF} \mathrm{-} \mathrm{Hydraulic} \mathrm{proof} \mathrm{testing} \\
\text { not being practiced. }\end{array}$ & $\begin{array}{l}\text { - Hydraulic Proof testing to be } \\
\text { done. }\end{array}$ \\
\hline Bulk Density & $\begin{array}{l}\text { - Fired Bulk Density always above } 2.35 \\
\text { gm/cc for Silica products. }\end{array}$ & - Maintain the process. \\
\hline
\end{tabular}

Table 5: Analysis of Individual Heads of Fish Bone Diagram - Assembly

\begin{tabular}{|c|c|c|}
\hline Sub Heads & Observations & Action Plan \\
\hline Cement Curing & $\begin{array}{l}\text { - Curing time is } 2 \text { Days in Water and } 3 \text { Days in Air. } \\
\text { - Observed delay in sending to Water curing and } \\
\text { less water curing, than } 2 \text { days. } \\
\text { - Observed less Air Curing by } 3 \text { days. } \\
\text { - } \% \text { of deviation } 1 \% \text {. }\end{array}$ & $\begin{array}{l}\text { - Trial Designed to see the impact of } \\
\text { Curing. }\end{array}$ \\
\hline $\begin{array}{l}\text { Artisan- } \\
\text { Cementing } \\
\text { Process }\end{array}$ & $\begin{array}{l}\text { - Voids of Cement. } \\
\text { - Patch of area inside Caps - No cement } \\
\text { These are observed in the Test Samples, which failed } \\
\text { in lower strength. }\end{array}$ & $\begin{array}{l}\text { - Improving Supervision. } \\
\text { - Training to Operators. } \\
\text { - Cement Mortar Making process - } \\
\text { Under QC Supervision. }\end{array}$ \\
\hline $\begin{array}{l}\text { Cement } \\
\text { Strength }\end{array}$ & $\begin{array}{l}\text { - Cement Strength Batch wise and daily production } \\
\text { sample values are above the specified limit. } \\
\text { - Same Cement supplier. }\end{array}$ & \\
\hline $\begin{array}{l}\text { Cleaning of } \\
\text { Machine }\end{array}$ & $\begin{array}{l}\text { - Cement Mortar making machine cleaned after } \\
\text { every shift. }\end{array}$ & $\begin{array}{l}\text { - Plan to do it after every Batch of } \\
\text { Mortar making to avoid any } \\
\text { contamination. }\end{array}$ \\
\hline
\end{tabular}

Table 6: Analysis of Individual Heads of Fish Bone Diagram - Metal parts

\begin{tabular}{|l|l|l|}
\hline Sub Heads & Observations & Action Plan \\
\hline $\begin{array}{l}\text { Sharp Edge Inside } \\
\text { caps }\end{array}$ & $\begin{array}{l}\text { All the test samples were checked for this. We } \\
\text { have not observed any Sharp edge or extra metal } \\
\text { in those acceptance pieces. }\end{array}$ & $\begin{array}{l}\text { Incoming Inspection and control } \\
\text { are in Place. }\end{array}$
\end{tabular}




\begin{tabular}{|c|c|c|}
\hline $\begin{array}{l}\text { Micro-Crack in } \\
\text { Ball Pins }\end{array}$ & $\begin{array}{l}\text { Due to Micro-Crack, elongation of Ball pins } \\
\text { can happen. That will lead to EMS failure. } \\
\text { - No such Observation on test pieces. } \\
\text { - Surprise vendor Audit seen lapses of } 100 \% \\
\text { MPI testing in Ball Pins. }\end{array}$ & $\begin{array}{l}\text { - To do MPI testing In-house or by } \\
\text { our personnel at Vendors site. }\end{array}$ \\
\hline $\begin{array}{l}\text { Sharp Edge on } \\
\text { Ball Pins }\end{array}$ & - No observation in the samples. & $\begin{array}{l}\text { To evaluate the effect, Trial } \\
\text { conducted. } \\
\text { - Inform to all vendors to control. }\end{array}$ \\
\hline $\begin{array}{l}\text { Wall Thickness } \\
\text { Variation in caps }\end{array}$ & $\begin{array}{l}\text { - Supplier specific observation - } \\
\text { - No observation of Wall thickness Variation in } \\
\text { Acceptance samples. }\end{array}$ & \\
\hline
\end{tabular}

Table 7: Analysis of Individual Heads of Fish Bone Diagram - Visual Defects

\begin{tabular}{|l|l|l|}
\hline Sub Heads & Observations & Action Plan \\
\hline $\begin{array}{l}\text { Small Micro-Cracks } \\
\text { on Heads }\end{array}$ & $\begin{array}{l}\text { In the failed pieces, we have observed around } \\
40 \% \text { cases, there are micro cracks, which } \\
\text { cannot be detected in sorting, caused Puncture. }\end{array}$ & $\begin{array}{l}\text { 100\% Hydraulic proof testing } \\
\text { will eliminate these micro- } \\
\text { cracks. } \\
\text { from } 27^{\text {th }} \text { October } 2015,100 \% \\
\text { Hydraulic of all items started for } \\
\text { PG. }\end{array}$ \\
\hline $\begin{array}{l}\text { Small Grog missing } \\
\text { on cavity Wall/ }\end{array}$ & $\begin{array}{l}\text { In the failed pieces, we have seen } 5 \% \text { cases, } \\
\text { patches in the Cavity or Wall, no Grog } \\
\text { available. These had caused improper gripping } \\
\text { of cement with Porcelain and Metal. Resulted } \\
\text { in Puncture. } \\
\text { The area of Grog missing was around } 10 \mathrm{~cm} 2 .\end{array}$ & $\begin{array}{l}\text { A trial conducted to find out the } \\
\text { extent of the impact of missing } \\
\text { grog patch. }\end{array}$ \\
\hline $\begin{array}{l}\text { Grog on cavity } \\
\text { Corner }\end{array}$ & $\begin{array}{l}\text { The majority of cases, seen Grog on Cavity in } \\
\text { the failed pieces. } \\
\text { But the Puncture paths are not generated from } \\
\text { these points. }\end{array}$ & $\begin{array}{l}\text { A trial conducted to find out the } \\
\text { extent of the impact of grog on } \\
\text { the cavity. }\end{array}$ \\
\hline $\begin{array}{l}\text { Small Head } \\
\text { Chipping }\end{array}$ & $\begin{array}{l}\text { Small Chipped head, are seen on the failed } \\
\text { pieces. } \\
\text { But the puncture paths are not generated from } \\
\text { these points. }\end{array}$ & $\begin{array}{l}\text { A trial conducted to find out the } \\
\text { extent of the impact of Small } \\
\text { Chipped head can cause. }\end{array}$ \\
\hline
\end{tabular}

Based on observation of the failed samples and routine c. Lesser Air Curing by $24 \mathrm{hrs}$. samples, following points are taken up for Design of Experiments to validate root cause of failures.

\section{Corrective Action derived from the process 1:}

The corrective actions arising out of these experimentations are related to the process and manufacturing set up. The set of corrective actions as identified are given below -

1. Elimination of Sharp edge on the Ball Pins

2. No grog missing on the cavity wall.

3. Ensuring Cement curing discipline

Note- These are very specific information for the Global Insulator's manufacturing unit where the trials are conducted. Some of the details are not provided due to its nature of confidentiality.

The results of the Design of Experiment at Global Inulators Ltd., are tabulated below in Table 8: a. Delay 24 hrs. before sending water curing

b. Lesser water curing $24 \mathrm{hrs}$. 
IJIREEICE

International Journal of Innovative Research in Electrical, Electronics, Instrumentation and Control Engineering

ISO 3297:2007 Certified

Vol. 5, Issue 2, February 2017

Table 8: Results of the Design of Experiment for Porcelain Insulators

\begin{tabular}{|c|c|c|c|}
\hline \multirow[t]{2}{*}{ Parameters } & \multicolumn{3}{|l|}{ Cement Curing Process } \\
\hline & $\begin{array}{l}\text { Delay in } 24 \text { hrs. before } \\
\text { sending water curing }\end{array}$ & $\begin{array}{l}\text { Lesser water curing } 24 \\
\text { hrs. }\end{array}$ & $\begin{array}{l}\text { Lesser Air curing } \\
24 \mathrm{hrs}\end{array}$ \\
\hline $\begin{array}{l}\text { Sharp Edges of Cone Dia } \\
\text { (Ball pin) }\end{array}$ & $\begin{array}{l}\text { Impacting Puncture and } \\
\text { EMS }\end{array}$ & Impacting EMS & Impacting EMS \\
\hline Grog at cavity corners. & $\begin{array}{l}\text { Impacting Puncture and } \\
\text { EMS }\end{array}$ & No Impact & No Impact \\
\hline Lesser Head thickness & No Impact & No Impact & No Impact \\
\hline Chipped head thickness & No Impact & No Impact & No Impact \\
\hline $\begin{array}{l}\text { Empty grog patches over } \\
\text { grog surfaces (head) }\end{array}$ & No Impact & No Impact & No Impact \\
\hline $\begin{array}{l}\text { Empty grog patches over } \\
\text { grog surfaces (Cavity Pin) }\end{array}$ & Impacting Puncture & $\begin{array}{l}\text { Impacting Puncture } \\
\text { and EMS }\end{array}$ & No Impact. \\
\hline
\end{tabular}

Aspect2: Identify the scope of enhancing the performance of porcelain insulators through design modification:

For conducting the study, the authors have selected the Product, which has the history of failures. 10" $120 \mathrm{KN}$ Disc Insulators has been selected to conduct the study. Even though the product has proven track records for years, the objective of this study is to Enhance Electrical and Mechanical performance beyond theSpecified values which will increase the Build in Safety Factors to meet the changing environment and usage pattern, while keeping the basic Dimensions within Specified Limits.

Two possible areas are identified for modifications without changing Specification limits and external parameters. These two areas can enhance both Electrical and Mechanical properties of Disc Insulators and improve the Build in safety factors required in the present condition.

\section{The Two areas are -}

- Creepage distance increase (by increasing shell outer diameter within the Specified Diameter tolerance limits) for improvement in electrical characteristics.

a. Cavity Diameter increases without any change in design factors to improve hoop stress development during routine hydraulic proof testing and distribution of electrical stress inside the cavity.

\section{ANALYSIS OF THE RESULTS OF THE STUDY}

The results of this experimentation are showing encouraging directions for the porcelain insulators. Deep driving into the results given in Table 2 indicates

- The existing and modified samples are meeting specified dimensional requirements of the standards.
Existing Standard products meets all requirements as per Specification.

- Modified Samples are meeting all requirements and showing enhanced performances both in Electrical and Mechanical properties by another 5 to $10 \%$.

- After aging performances of Standard and Modified Samples are meeting all requirements.

- Though our existing Standard products are well above all specified requirement, while modified samples are having better build In Safety factors compared to existing Standard product. This modified product expected to perform better considering the present changing requirements.

\section{FINDINGS AND KEY LEARNING}

This article has attempted to review the current challenges being faced by the Electrical Transmission and distribution companies. The reliability of supply and long term performances are key areas of focus across the global electrical power supply companies. A significant advancement is made in electrical power system management and control. Efforts are being made for improving the reliability of the power system by providing uninterrupted power supplies, reduction of losses in transmission and distribution, efficient sharing of grids. At the same time, one of the major components in the system i.e Electrical insulators is seen a change in technology. New generation Electrical Insulators being introduced to improve the reliability particularly areas under high pollution zones (Coastal zone etc).

Through this research project, significant knowledge and information are gathered and the researcher is able to conduct experiments with conclusive results. The research Questions which are raised at the beginning of the article, being answered effectively. 
The salient points are -

- A power outage is a significant phenomenon and it is existing for a long time. In recent time the occurrences seem to increase. But it can be related to the increased network and increased power generation and distribution system.

- Major reason for any power outage primarily seen as weather, especially in US and Europe but it is more related to the failure of Insulators of grid management in Asian countries.

- The impact of pollution is significant in the performance of electrical insulators, particularly Porcelain Insulators.

- Though Porcelain Insulators has a proven history for more than 100 years, it is now facing challenges from new generation insulators made out of composites. Composites insulators are preferred over Porcelain Insulators due to its unique hydrophobic properties and higher reliability in Polluted areas.

- The growth of Polymeric Insulators has been stagnant since 2010 due to its failure and lower life.

- It seems a co-existing model is evolving in the transmission and distribution system, where both Porcelain and Polymeric Insulators are used depending on location, pollution severity.

- An alternate is also developed comprising both Porcelain and bit of Polymers. RTV coated porcelain insulators are finding their market. It is certainly providing both of Porcelain and Polymer properties. But again the life of this RTV coating, handling and additional cost not allowing it to spread faster.

- The quantitative research conducted showing the clear and effective solution for the Porcelain Insulators.

- Porcelain Insulators as seen are prone to Electrical Puncture due to its inherent properties and manufacturing processes. The systematic study has revealed that

- Few key parameters, if controlled better, can significantly reduce the puncture failure tendency of porcelain.

- These parameters are not difficult to control but their significance is established through the design of experiments.

- It is also possible to enhance the performance of porcelain insulators by $5-10 \%$ from the existing level by slightly modifying the existing design.

o The changes in the design not call for customer verification and can be done very easily.

○ Key performance values like EMS, Oil Puncture are showing improvement by $5-10 \%$. This gives additional cushions to the built is safety factors.

- After aging performances also showing better electrical performance over existing design.

A systematic approach with the specific objective, we can improve the performance of existing Porcelain insulators and can provide business sustenance.
Probably this study may be a one-off study done in Porcelain Insulators manufacturing Industries and trust the outcome to have a wider ramifications for improving the performance of porcelain Insulators against pollution, and thus provide a solution to the Industry for its future growth.

In the process of conducting this research project many leanings have taken place.

- The first and foremost learning is - how to coin the best phrase to get the right Literature from the available resources.

- Effective use of statistical tools can solve any complex problem.

- Approach any problem with an open mind and clearly, define the problem. This will help in solving the problem effectively.

\section{LIMITATION}

This cases study, has been mainly concerned with the assembled Insulators and its parts. It was not focused on porcelain manufacturing and kiln function. Our concentration will be on metal, cement, and cementing process. Though we can complete our validation process in the time frame, but if we have to get the hypothesis tested at the National or International Laboratories, we will not be able to do so in the given time frame.

\section{SCOPE FOR FURTHER STUDY/RESEARCH}

The study has been shared with the management and the implementation of the new control system and design is in the process of Implementation. A similar study with other SKU's is taken up to enhance performance across the product range. Redesigning the porcelain insulators by increasing leakage path are in the process of development. This will further strengthen the position of Porcelain Insulators.

Due to the limitation of time, some more aspect of Manufacturing is not covered in this study. As a next step to optimize and making the process robust, the similar study will be taken up in the other section of Manufacturing.

\section{REFERENCES}

[1] Andy Schwalm, 2010, Report on Insulators 101" Section A - IEEE Chairman, Lightning and Insulator Subcommittee proceedings of Transmission and Distribution Conference and Exposition New Orleans, Louisiana ,April 20, 2010

[2] Aditya Birla Insulators, India - Data Base, http://www.adityabirlainsulators.com/

[3] Central Electricity Authority (CEA), Government of India Ministry of Power Report of the inquiry committee on grid incident in northern region on $7^{\text {th }}$ and $9^{\text {th }}$ March, 2008.

[4] Christine Chang, 2016, Cause of overhead insulation failure, Published report from Fujian Electronics on June 27, 2016 in Course Hero- Open web source 


\section{IJIREEICE \\ International Journal of Innovative Research in \\ Electrical, Electronics, Instrumentation and Control Engineering \\ ISO 3297:2007 Certified}

Vol. 5, Issue 2, February 2017

[5] C. Muniraj, K.Krishnamoorthi and S.Chandrasekar, (2013). Investigation on Flashover Development Mechanism of Polymeric Insulators by Time Frequency Analysis, Journal of Electr Eng Technology, Vol. 8, No. 6, 2013.

[6] INMR (2012), Modern Pollution Monitoring principles allow better selection of insulators for better polluted conditions, article by Igor Gutman and Wallace Vosloo in INMR, June 2012.

[7] INMR (2015), 12 Examples of Insulator Failures, article in INMR of 24 Dec 2015.

[8] INMR (2016), Global Demand for Insulators and Bushings, article in INMR of Sept 2016.

[9] INMR (2016), Hydrophobicity Transfer of Silicon Rubber, article in INMR of Dec 2016

[10] Parmelee, C. W., \& Kraehenbuehl, J. O. (1935). Mechanicalelectrical stress studies of porcelain insulator bodies; a report of an investigation conducted by the Engineering Experiment Station, University of Illinois, in cooperation with the Utilities Research Commission. University of Illinois bulletin; v. 32, no. 31.

[11] Parihar, V. S., \& Kori, A. K. Analysis of Leakage Current of $220 \mathrm{kV}$ Long Rod Insulators at Different Severity Level of Salt Contamination, International Journal of Science and Research (IJSR) ISSN (Online): 2319-7064 Index Copernicus Value (2013): $6.14(2015)$

[12] R.S.Gorur (2011), 'Failure modes of Porcelain and toughened glass suspension insulators, published IEEEExplore.ieee.org/ document 5596150

[13] Sourabh Lodha (2016). Power Grid Failure, Department of Electrical Engineering CDSE, IIT/Mumbai report of 13 Dec 2016 appearing at http://www.cdgi.edu.in/doc/Power\%20Grid\%20 Failure.pdf 